УДК 346:548

DOI https://doi.org/10.32849/2663-5313/2020.12.11

\title{
Світлана Подоляк,
}

канд. юрид. наук,

доцент кафедри господарського та адміністративного права

факультету соиіологї та права

Національного технічного університету Украйни

«Київський політехнічний інститут імені Ігоря Сікорського»

\section{КОМПЛАЄНС-КОНТРОЛЬ У ДІЯЛЬНОСТІ ЮРИДИЧНИХ ОСІБ В УКРАЇНІ}

У статті проводиться дослідження поняття та правової сутності комплаєнс-контролю як засобу самоорганізацї господарської діяльності юридичних осіб, спрямованої на врахування ризиків, у тому числі підприємницьких, та попередження можливих правопорушень.

Традииійна модель комплаєнсу широко застосовується в краӥнах системи загального права, де на досить високому рівні перебувають бізнес-культура, відкритість і декларування поведінки господарюючих осіб, з огляду на те, що порушення обов'язкових вимог може привести не тільки до фінансових втрат, а інколи і до ліквідачї юридичної особи, $і$ до кримінальної відповідальності. Юридичні особи використовують комплаєнс також як систему захисту бізнесу від корупиї $і$ зловживань.

В Украйні комплаєнс-контроль застосовується в основному юридичними особами - представниками так званого великого бізнесу. Малий та середній бізнес майже не мають реально діючого комплаєнс-контролю. Очевидно, це пов'язано із відсутністю чіткого правового регулювання у такій галузі й також із недостатністю у господарюючих осіб усвідомлення щодо економічних переваг та результатів його застосування.

Перші кроки у правовому регулюванні та застосуванні комплаєнс-контролю в Україні були зроблені у фінансово-банківський сфері, в якій було визначено повноваження підрозділу комплаєнсу, який має входити до системи внутрішнього контролю та разом з підрозділом управління ризиками має стати другою лінією захисту ефективного управління ризиками.

До найголовніших тендениій для юридичних осіб, які прачюють в інших галузях, можна віднести антикорупиійний комплекс нормативно-правових актів. Оскільки законодавство не завжди зобов'язує суб'єктів господарювання застосовувати комплаєнс-контроль, то че і не знаходить відображення в компетенціях суб'єкта господарювання.

Тому можна зазначити, що хоча в чинному законодавстві України і створені певні умови розвитку комплаєнс-контролю в господарській діяльності юридичних осіб, але иього не досить. Комплаєнс-контроль має стати звичним інструментом для сучасних реалій для тих, що хочуть стати привабливими для іноземного інвестора, партнера

Ключові слова: комплаєнс-контроль, юридичні особи, антикорупційний комплаєнс, комплаєнсризик, ризик-орієнтований підхід.

Постановка проблеми. У сучасних реаліях інтеграції українського бізнесу не тільки в європейську, але й у світову економіку, для яких притаманне дотримання основних принципів комплаєнс-контролю як результативного інструмента мінімізації ризиків, виникає необхідність застосування нових форм господарювання. Їх ефективна реалізація дає можливість мінімізувати правові та репутаційні ризики, які напряму впливають на ефективність бізнесу та на його прибутковість. 3 огляду на те, що рівень нефінансових ризиків постійно зростає, одночасно збільшується цінність для бізнесу комплаєнс-контролю. Тому запровадження українськими юридичними особами процедур комплаєнс-контролю дає їм можли-

вість підвищити свою конкурентоздатність на світовому ринку та запобігти порушень законодавства у здійсненні господарської діяльності.

Аналіз останніх досліджень та публікацій. Натепер питання комплаєнс-контролю досліджуються як науковцями, так і практикуючими юристами.

Метою статті є розкриття правової сутності комплаєнс-контролю як правового інструмента попередження ризиків та практики його застосування юридичними особами.

Виклад основного матеріалу дослідження. Термін комплаєнс походить від англійського дієслова to comply - відповідати, тобто комплаєнс являє собою відповід- 
ність будь-яким внутрішнім або зовнішнім вимогам або нормам. За визначенням Міжнародної асоціації комплаєнсу, комплаєнс - це забезпечення відповідності діяльності встановленим вимогам та стандартам [1].

Базельський комітет 3 банківського нагляду визначив комплаєнс-ризик як ризик застосування юридичних санкцій або санкцій регулюючих органів, суттєвого фінансового збитку або втрати репутації банком як наслідку недотримання ним законів, інструкцій, правил, стандартів саморегулюючих організацій або кодексів поведінки, які стосуються банківської діяльності. Отже, застосування комплаєнсу прийшло із банківської галузі, де він використовувався для мінімізації ризиків у галузі протидії відмиванню доходів та фінансуванню тероризму Нині юридичні особи використовують комплаєнс як систему захисту бізнесу від корупції, а також зловживань. У розробці та використанні комплаєнс-контролю зацікавлені як власники бізнесу, так і топ-менеджери, оскільки порушення обов'язкових вимог призводить не лише до фінансових втрат, а й інколи до ліквідації юридичної особи, а можливо й до кримінальної відповідальності топ-менеджерів.

Натепер в Україні комплаєнс-контроль застосовується в основному юридичними особами, які належать до представників так званого великого бізнесу, наприклад, група ДТЕК з 2010 року навіть має спеціальний підрозділ - службу комплаєнсу [2], ПАТ ВФ «Україна» (Vodafone) також [3]. Комплаєнс застосовується і у діяльності державних підприємств, наприклад, ДП НАЕК «Енергоатом» [4], Нафтогаз [5]. Малий та середній бізнес, на жаль, майже не мають реально діючого комплаєнс-контролю. Ймовірно, це пов'язано із тим, що немає чіткого правового регулювання у цій галузі, є недостатність певного усвідомлення щодо призначення, економічних переваг та результатів застосування комплаєнс-контролю, а можливо, й переконання, що введення комплаєнс-контролю, з огляду на невеликі розміри діяльності, не буде для них мати жодного ефекту.

Україна робить лише свої перші кроки у правовому регулюванні та застосуванні комплаєнс-контролю. Найбільше він застосовується у фінансово-банківській галузі. Рішенням Правління Національного Банку України від 03.12.2018 року № 814-рш було схвалено Методичні рекомендації щодо організації корпоративного управління в банках України, де визначаються повноваження підрозділу комплаєнсу, який входить до ефективної системи внутрішнього контролю та разом з підрозділом з управління ризиками є другою лінією захисту ефективного управління [6]. Для юридичних осіб, які працюють в інших галузях, до основних нормативно-правових актів можна віднести Закон України «Про запобігання корупції», Закон України «Про публічні закупівлі», Кримінальний кодекс України, Кодекс про адміністративні правопорушення.

Аналіз зарубіжних практик здійснення комплаєнс-контролю показує, що світова спільнота визначає стандарти ведення бізнесу по всьому світу і безпосередньо впливає на питання стабільності глобальної економіки та бізнесу конкретної компанії. Цікавим є такий приклад: якщо материнська компанія юридичної особи (зареєстрованої за законодавством України) зареєстрована або розміщує цінні папери у відповідних іноземних юрисдикціях, то вона зобов'язана також застосовувати у комплаєнс-контролі, а саме у разі антикорупційного комплаєнсу, законодавство цих країн. Найпоширенішими є Закон США «Про протидію корупції за кордоном» (Foreign Corrupt Practice Act, 1977), Закон Великої Британії «Про боротьбу 3 хабарництвом» (UK Bribery Act, 2010), Закон Франції «Про прозорість, боротьбу з корупцією та модернізацію економіки» (Sapin II, 2016) та інші. Застосування законодавства цих країн передбачає, що й відповідні санкції будуть застосовуватись згідно з цим законодавством. Так, відповідно до Закону США «Про протидію корупції за кордоном» санкцією для фізичної особи за порушення відповідних положень щодо хабарів є штраф до 100000 доларів США та/або позбавлення волі на строк до 5 років, за порушення положень щодо звітності штраф до 5 мільйонів доларів США та/або позбавлення волі на строк до 20 років. Закон Великої Британії «Про боротьбу з хабарництвом» передбачає для фізичних осіб штраф, який не обмежений у розмірі, та до 10 років позбавлення волі. Для юридичних осіб Закон США «Про протидію корупції за кордоном» передбачає за порушення положень щодо хабарів штраф у розмірі до 2 мільйонів доларів США, за порушення положень щодо звітності - штраф до 25 мільйонів доларів США та/чи двократний розмір суми отриманої вигоди. Закон США «Про протидію корупції за кордоном» передбачає й для фізичних осіб штраф, який не обмежено у розмірі, а також відсторонення від участі у тендерах за участю країн $\mathrm{CC}$.

Як приклад застосування вищезазначеного законодавства можна навести таку справу: у 2006 році було встановлено, що компанія Siemens протягом майже 10 років 
систематично давала хабарі в Іраку, Венесуелі, Бангладеш, Аргентині, Франції, Нігерії, Туреччині, Італії, Китаї, Ізраїлі, В’єтнамі, Росії і Мексиці. За результатами розслідування було виявлено близько 1,5 млрд доларів сумнівних платежів, 3 них 805 мільйонів - підтверджені корупційні платежі. Siemens сплатив штрафи: 350 мільйонів доларів США - Комісії з цінних паперів та бірж, 450 мільйонів доларів США - Міністерству юстиції; та 800 мільйонів доларів США німецькій владі. На чотири роки був призначений незалежний спостерігач [7].

Практика здійснення комплаєнс-контролю дає змогу виділити як його об'єкт три види ризиків:

- операційний: контроль виробничих та технологічних процесів;

- правовий: контроль механізму дотримання нормативно-правових та локальних актів юридичної особи;

- репутаційний: контроль вибору контрагентів, моніторинг новин у засобах масової інформації про юридичну особу, керівництво, співробітників тощо.

Взагалі розуміння комплаєнсу як системи управління ризиками прояву негативних факторів під час здійснення діяльності відображено у стандарті ISO 19600-2014 "Compliance management systems - Guidelines".

Узагальнюючи світовий досвід використання комплаєнс-контролю в діяльності юридичних осіб, можна виокремити декілька «традиційних» політик комплаєнс-контролю, які застосовуються юридичними особами:

- Кодекс корпоративної етики - це загальний регламент, в якому прописані всі основні аспекти діяльності юридичної особи, у тому числі що стосується морально-етичних принципів, стандартів поведінки, пріоритетів та обов'язків співробітників.

- Політика протидії відмиванню доходів, отриманих злочинним шляхом та фінансування тероризму. Наявність такої політики попереджає потрапляння злочинно нажитих доходів у легальний сектор економіки та попереджує фінансування тероризму.

- Політика отримання та дарування подарунків - зазвичай у ній розмежовують, коли подарунок буде вже розглядатися як хабар або відкат. Наявність такої межі попереджає можливість маніпулювання посадовою особою юридичної особи з певною метою. Така політика загалом не повинна обмежувати дарування, а обмежує вартість подарунка та забезпечує контроль подарунків.

- Політика інформування про порушення етичних стандартів - правильно про- писана політика дає можливість ефективно боротись із порушеннями всередині компанії. Зазвичай вона передбачає право на анонімність, а також процедуру розслідування та документування виявлених порушень.

- Політика для регулювання конфлікту інтересів регламентує порядок дій у ситуаціях, коли інтереси співробітника можуть суперечити інтересам юридичної особи, а також коли інтереси одного контрагента можуть суперечити інтересам іншого тощо. Така політика встановлює зобов'язання співробітника попереджати виникнення конфліктів інтересів, а також встановлюється, що інтереси юридичної особи повинні превалювати над інтересами окремо взятого співробітника.

- Політика взаємодії із державними органами регулює процедуру ефективної та правильної взаємодії із державними органами.

- Політика щодо конфіденційної інформації регламентує нерозголошення даних клієнтів та інформацію по угодах із ними. Вона визначає не тільки формування загальної культури поводження з даними клієнтів, а й забезпечення зберігання та стандартів поводження із персональними даними.

- Політика контролю купівлі цінних паперів співробітниками компанії. Ця політика потрібна для юридичних осіб, які працюють на ринку цінних паперів. Може бути встановлена заборона на купівлю цінних паперів юридичних осіб, з якими співпрацюють, для особистих цілей, також регламентується спеціальний порядок погодження такої купівлі за певних вимог. Це дає змогу уникнути нецільового використання робочого часу, службової інформації з метою особистого збагачення, уникнути звинувачень в неетичній поведінці співробітників на ринку цінних паперів.

- Політика «китайської стіни» в основному застосовується в юридичних особах, які працюють у фінансовому секторі, з метою попередження конфлікту інтересів та забезпечення умов для чесної конкуренції. У відповідності до принципу «китайської стіни» підрозділи юридичної особи поділяються на дві категорії залежно від того, якою інформацією володіють: «приватна сторона» - підрозділи, які в межах своїх функціональних обов’язків отримують доступ до непублічної інформації щодо клієнта (фінансовий стан, інвестиційні плани, підрозділи, які в межах своїх функціональних обов'язків отримують доступ до непублічної інформації), яка може надати переваги їі володільцеві, «публічна сторона» - підрозділи, які в межах своїх функціональних обов'язків не отримують 
доступ до непублічної інформації. Доступ до непублічної інформації надається співробітнику «публічної сторони» лише після надання згоди на це відділом комплаєнсу та за погодження з керівником підрозділу «приватної сторони». Співробітник, який через свої функціональні обов'язки має доступ до інформації «приватної» та «публічної» сторони, отримує статус «над стіною», що надається підрозділом комплаєнсу.

- Політика контролю добросовісності контрагентів та клієнтів визначає, що юридичні особи повинні ідентифікувати та встановити контрагента (його бенефіціарного власника), його репутацію тощо перш ніж провадити із ним бізнес-операції.

- Політика контролю реагування на скарги регламентує шлях отриманої скарги, процедуру проведення її розгляду на надання відповіді.

- Політика контролю підвищення кваліфікації співробітниками.

Наявність політик щодо комплаєнсконтролю може бути умовою для укладання договору 3 юридичною особою-нерезидентом. Для ефективного запровадження системи комплаєнс-контролю в діяльності юридичної особи є необхідним не лише наявність прописаних політик, а й особи, яка відповідає за їх реалізацію та постійне оновлення, оскільки як правове регулювання, так і бізнес-процеси змінюються Таку особу називають комплаєнс-менеджером або комплаєнс-офіцером. Для дієвості затверджених політик 3 комплаєнс-контролю є також важливою підпорядкованість комплаєнс-менеджера, яка повинна бути за рівнем не нижчою за заступника керівника юридичної особи.

Під час розробки політик комплаєнсконтролю необхідно розуміти, що вони не повинні обмежувати бізнес, а повинні лише мінімізовувати ризики. Встановлення такого розмежування є дуже важливим, оскільки воно дає можливість найбільш ефективно організувати діяльність юридичної особи та інтегрувати комплаєнс-контроль без конфліктів 3 іншими бізнес-процесами. Комплаєнс-контроль дає змогу юридичній особі зменшувати ймовірність застосування різноманітних санкцій, мінімізувати фінансові втрати, а інколи й уникнути банкрутства та ліквідації; попереджувати ризики втрати ділової репутації; попереджувати факти шахрайства, корупції та зловживань; знижувати ризики взаємодії із контрагентами; збільшувати ефективність бізнес-процесів; збільшувати вартість компанії, а відповідно, і її конкурентоспроможність та інвестиційну привабливість.
Юридична особа повинна «відчувати», що застосування комплаєнс-контролю є для неї необхідним, оскільки найчастіше вона займається саме підприємницькою діяльністю, яка здійснюється нею самостійно та на власний ризик. Власне, підприємницька діяльність, яка здійснюється в спеціальних організаційно-правових формах, iз наймом персоналу, щодо невизначеного кола осіб, має спеціальне правове регулювання залежно від сфери економіки, де містяться санкції за порушення, й повинна бути об'єктом комплаєнс-контролю. В Україні передбачена свобода підприємницької діяльності, що має свій відповідний ризик щодо наслідків дії (бездіяльності). Підприємницький ризик може мати як позитивні, так і негативні майнові наслідки діяльності. Це можуть бути як об'єктивні причини - стихійні лиха, якісь непередбачувані обставини, які можна намагатися зменшити, наприклад, через страхування; так і суб'єктивні наслідки - правопорушення власне юридичною особою або з боку третіх осіб щодо неї. Ніхто не може гарантувати результат підприємницької діяльності, оскільки він залежить від великої кількості внутрішніх та зовнішніх факторів, наприклад, професійності топменеджерів, контрагентів, споживачів тощо. Врахувати все неможливо, тому керівництво юридичної особи постійно ризикує, вибираючи ту чи іншу стратегію ведення бізнесу, поведінки на ринку.

Таким чином, можна зазначити, що комплаєнс-контроль повинен враховувати такі принципи, як: відповідність системи контролю юридичної особи важливим для іï діяльності факторам; відповідальність керівних органів за загальний контроль і управління комплаєнс-ризиками; співставність комплаєнс-процедур потенційним ризикам, прозорість та постійність комплаєнс-процедур; відповідальність та невідворотність покарання.

Водночас, незважаючи на значні переваги комплаєнс-контролю, його застосування малим та середнім бізнесом не завжди доцільно, оскільки здебільшого затрати на нього можуть суттєво перебільшити його економічний ефект і це потребує оцінки. При цьому можна виокремити такі категорії господарюючих суб'єктів малого та середнього бізнесу, для яких забезпечення безпечного функціонування неможливе без застосування комплаєнс-контролю:

- підприємства, діяльність яких підлягає обов'язковому ліцензуванню;

- організації, продукція яких, послуги або робочі місця потребують обов'язкової сертифікації, а їх діяльність регламентується певними стандартами; 
- підприємства, які працюють або планують свою діяльність у сфері державних замовлень та закупок;

- господарюючі суб'єкти, які за специфікою своєї діяльності мають значну кількість контрагентів (постачальників, підрядників, покупців, замовників).

Вищезазначене підтверджує необхідність розробки для них окремих методик функціонування комплаєнс-контролю.

Проведений аналіз дає нам можливість запропонувати авторське визначення комплаєнсу як соціально-правової господарської системи організації (у тому числі самоорганізації) управління можливими ризиками невідповідності господарської діяльності юридичної особи нормам права з метою мінімізації або попередження суттєвих збитків та втрати репутації не тільки самого господарюючого суб'єкта, але і взаємодіючих з ним суб'єктів.

\section{Висновки}

Підсумовуючи викладене, можна стверджувати, що комплаєнс-контроль як частина системи управління юридичною особою має бути інтегрованим у бізнес-процеси юридич- ної особи у розрізі контролю як співробітників, так і документів з метою дотримання внутрішніх та зовнішніх стандартів.

\section{Список використаних джерел:}

1. International compliance association. URL: https://www.intcomp.org/careers/a-career-incompliance/what-is-compliance/ (дата звернення: 17.11.2020).

2. ДТЕК. URL: https://dtek.com/ru/ investors_and_partners/ethics_and_compliance (дата звернення: 17.11.2020).

3. ПАТ ВФ «Україна». URL: https://www. vodafone.ua/ru/company/partneram/compliance (дата звернення: 17.11.2020)

4. ДП НАЕК «Енергоатом». URL: http:// www.energoatom.com.ua/ua/komplaens-17/ corporate_rules-167 (дата звернення: 17.11.2020).

5. Нафтогаз. URL: https://gas.ua/uk/ compliance (дата звернення: 17.11.2020).

6. Рішення Правління Національного Банку України від 03.12.2018 року № 814-рш. URL: $\quad$ https://zakon.rada.gov.ua/laws/show/ vr814500-18\#Text (дата звернення: 17.11.2020).

7. Siemens Calls More Transactions Suspicious. URL: https://www.wsj.com/articles/ SB119083161944740178 (дата звернення: 17.11.2020).

\section{Svitlana Podoliak. Compliance control in legal entities activity in Ukraine}

In the article the concept and legal essence of compliance control as self-organization of economic activity of legal entities is examined.

The traditional model of compliance is widely used in countries with common law system. Business culture, openness and clearness of legal entities activity are at high level. Violation of mandatory requirements can lead not only to financial losses, but sometimes to the termination of legal entities, and to criminal liability. Legal entities also use compliance as a system for protecting business from corruption and misuse.

In Ukraine compliance control is used mainly by legal entities - representatives of the so-called big business. Small and medium-sized business entities have almost no real compliance control. That could be so because of the lack of clear legal regulation in this area and also lack of awareness among businessmen about the economic benefits and the results of its application.

The first steps in the legal regulation and application of compliance control in Ukraine were made in the financial and banking sector, which defined the responsibility of the compliance unit, which should be a part of the internal control system and together with the risk management unit should become the second line of effective risk management.

The anti-corruption set of regulations is among the most important trends for legal entities working in other industries. As the law does not always oblige business entities to apply compliance control, this is not reflected in the competence of the business entity.

Therefore, it can be noted that although the current legislation of Ukraine creates certain conditions for the development of compliance control in the economic activities of legal entities, but this is not enough. Compliance control should become a familiar tool for today's realities for those who want to become attractive to a foreign investor, partner.

Key words: compliance control, legal entities, anticorruption compliance, compliance-risk, riskmanagement approach. 